\title{
Generalizált epilepszia hátterében azonosított ioncsatorna-génmutáció ritka formája
}

\author{
Till Ágnes dr. ${ }^{1}$ - Szalai Renáta dr. ${ }^{1,2}$ \\ Hegyi Márta dr. ${ }^{3}$ - Kövesdi Erzsébet dr. ${ }^{1,2}$ - Büki Gergely ${ }^{1}$ \\ Hadzsiev Kinga dr. ${ }^{1,2}$ - Melegh Béla dr. ${ }^{1,2}$ \\ ${ }^{1}$ Pécsi Tudományegyetem, Általános Orvostudományi Kar, Klinikai Központ, Orvosi Genetikai Intézet, Pécs \\ ${ }^{2}$ Pécsi Tudományegyetem, Szentágothai János Kutatóközpont, Pécs \\ ${ }^{3}$ Magyar Református Egyház Bethesda Gyermekkórháza, Neurológia Osztály, Budapest
}

\begin{abstract}
A molekuláris genetikai technológiák fejlődése következtében egyre több, korábban idiopátiásnak tartott betegség hátterében ismerjük meg a genetikai eltérést. A generalizált epilepsziában szenvedő, a betegség lefolyása során epilepsziaszindrómát váltó, jó intellektusú, kiterjedt hipopigmentált folttal rendelkező fiúgyermek célzott genetikai vizsgálata neurocutan szindróma irányába nem hozott eredményt. Teljesexom-szekvenálás során egy kálium-klorid-kotranszporter génjének heterozigóta misszensz mutációja igazolódott, ami a fenotípussal összevetve, az irodalomban az idiopátiás generalizált epilepszia 14-es típusaként ismert epilepsziaszindróma diagnózisát támasztja alá.

Orv Hetil. 2019; 160(21): 835-838.
\end{abstract}

Kulcsszavak: idiopátiás generalizált epilepszia, SLC12A5, teljesexom-szekvenálás, TSC1, TSC2

\section{A rare form of ion channel gene mutation identified as underlying cause of generalized epilepsy}

\begin{abstract}
The advances in molecular genetic methods has lead to the discovery of the genetic alterations that underlie the etiology of most diseases previously held to be idiopathic. Targeted genetic examination of a pediatric male patient showing a normal intellect, an extended area of skin hypopigmentation, and suffering from generalized epilepsy displaying a switch in epilepsy syndrome during the course of the disease towards a neurocutaneous syndrome was unsuccessful. Whole-exome sequencing identified a heterozygous missense mutation in a potassium chloride cotransporter gene, which together with the phenotype underscores the diagnosis of an epilepsy syndrome known in the literature as idiopathic generalized epilepsy type 14 .
\end{abstract}

Keywords: idiopathic generalised epilepsy, SLC12A5, whole-exome sequencing, TSC1, TSC2

Till Á, Szalai R, Hegyi M, Kövesdi E, Büki G, Hadzsiev K, Melegh B. [A rare form of ion channel gene mutation identified as underlying cause of generalized epilepsy]. Orv Hetil. 2019; 160(21): 835-838.

(Beérkezett: 2019. január 3.; elfogadva. 2019. január 21.)

\section{Rövidítések}

$\mathrm{AD}=$ autoszomális domináns; $\mathrm{AR}=$ autoszomális recesszív; DNS $=$ dezoxiribonukleinsav; EDTA $=($ ethylenediaminetetra acetic acid) etilén-diamin-tetraecetsav; EEG = elektroencefalográfia; EIMFS = (epilepsy of infancy with migrating focal seizures) korai migráló fokális epilepszia; $\mathrm{GABA}=$ (gamma-aminobutyric acid) gamma-aminovajsav; IGE = idiopátiás generalizált epilepszia; MLPA = (multiplex ligation-de- pendent probe amplification) multiplex ligatiofüggő próbaamplifikáció; $\mathrm{MR}=$ (magnetic resonance) mágneses rezonancia; $\mathrm{PCR}=$ polimeráz-láncreakció; $\mathrm{PET} / \mathrm{CT}=($ positron-emission tomography/computed tomography) pozitronemissziós tomográfia/számítógépes tomográfia; VUS = (variant of uncertain significance) bizonytalan jelentőségű változat; WES = (whole-exome sequencing) teljesexom-szekvenálás 
A molekuláris genetikai technológiák robbanásszerü fejlódése forradalmasította a medicina szinte valamennyi területét. Az adott betegpopulációkban elvégzett teljesexom-, illetve teljesgenom-szekvenálás eredménye óriási ismeretanyaghoz juttatja a kutatókat és a klinikusokat az adott betegség genetikai okait és hajlamosító tényezőit illetően. Az epilepsziák legújabb terminológiája és klaszszifikációja már figyelembe veszi az új molekuláris genetikai ismereteket is [1]. Az „idiopátiás” terminológia kezd kiszorulni, hiszen egyre több epilepsziaszindróma genetikai hátterét ismerjük, ezért a korábban idiopátiás generalizált epilepszia szindróma helyett a genetikus generalizált epilepszia a helyes terminológia. Az ismert, epilepsziát okozó gének fenotípusos heterogenitást, az epilepsziaszindrómák nagy része pedig genetikai heterogenitást mutat. A pontos genetikai diagnózis elengedhetetlen feltétele az érintett család genetikai tanácsadásának, a magzati vizsgálat felajánlásával pedig segítheti a pozitív családtervezést, és sok esetben terápiás konzekvenciával is jár.

\section{Esetismertetés}

A negatív családi anamnézisü, jelenleg 14 éves fiúbeteg a mater I/1. graviditásából, a 4l. gesztációs hétre, 2900 g születési súllyal, jó általános állapotban született. Apgarérték: 10-10. A magzati ultrahangvizsgálata során ábrázolódó plexus chorioideus ciszta miatt a 2 . trimeszterben amniocentesis történt, a kromoszómavizsgálat normál férfi kariotípust mutatott. Cardiorespiratoricus adaptációja rendben zajlott, korai pszichomotoros fejlődése jó ütemú volt. Két és fél éves korában indult az epilepsziája astaticus myoclonus szindróma formájában, majd kisiskolás korában szindrómaváltás következett be, absence rohamai jelentkeztek. Kezdetben csak hármas antiepileptikumkombináció mellett volt rohammentes, jelenleg monoterápiaként lamotrigint szed, és 5 éve nem volt rohama. A gyógyszer dózisának csökkentése viszont görcsöt provokált, így az antiepileptikumot leépíteni nem lehetett. Alvásmegvonásos EEG-vizsgálata során generalizált interictalis epileptiform jelek igazolódtak. Epileptogén fókuszként a koponya-MR-vizsgálat és a PET/ CT-vizsgálat alapján a jobb frontális érképletek körüli szürkeállomány szerepe merült fel. A megszületéstól észlelt, a bal testfélen elhelyezkedő, szegmentális jellegü, Blaschkó-vonalat követő, a középvonalat megtartó, kiterjedt hipopigmentált folt, a diszkrét koponya-MR-eltérés és az epilepszia együttes előfordulása felvetette a neurocutan szindróma lehetôségét. Intézetünkben 9 évesen vizsgáltuk először, ekkor belszervi és neurológiai statusából a hipopigmentált folton kívül kiemelendő nem volt, lényeges dysmorphiát nem észleltünk (1. ábra). Bár a diagnosztikus kritériumrendszer alapján a sclerosis tuberosa klinikai diagnózisát felállítani akkor nem lehetett, genetikai vizsgálatainkat ez irányba indítottuk. Betegünk jelenleg 8. osztályos, kognitív funkciói kiválóak, kitúnő tanuló.

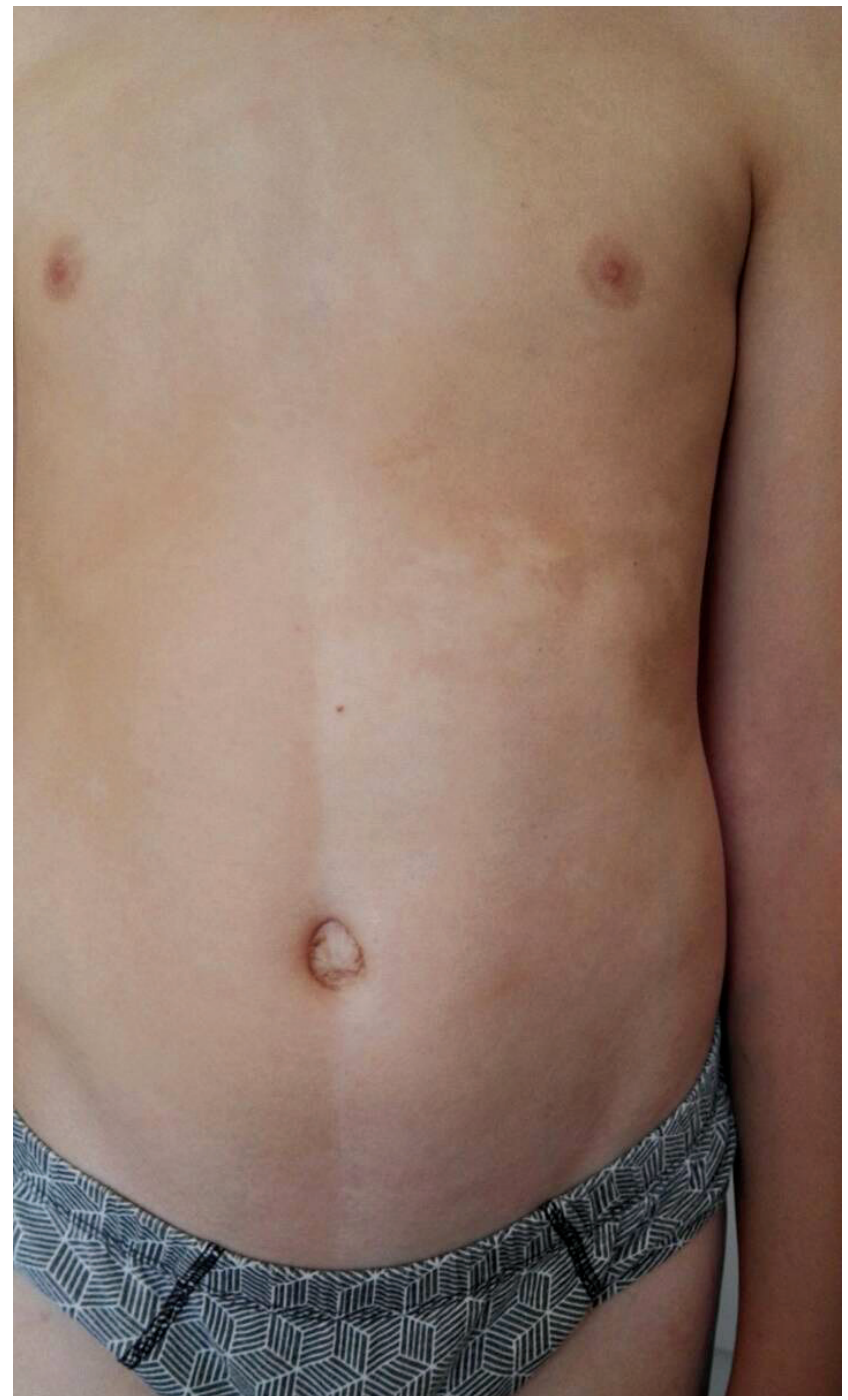

1. ábra

| A beteg bőrtünete

\section{Módszer}

A Pécsi Tudományegyetem Orvosi Genetikai Intézetének genetikai tanácsadójában részletes fenotípuselemzést végeztünk, betegünket a humángenetikai törvénynek megfelelően genetikai tanácsadásban részesítettük. A beteg törvényes képviselője írásos beleegyezését adta a genetikai vizsgálatok elvégzéséhez. A DNS-minta tárolása, a vizsgált személy eredményeinek tudományos közleményben történő felhasználása az Egészségügyi Tudományos Tanács Tudományos és Kutatásetikai Bizottságának jóváhagyásával történt; a helsinki nyilatkozat (1971) irányelveit követtük.

A molekuláris genetikai vizsgálatokhoz EDTA-val alvadásgátolt perifériás leukocytákból E.Z.N.A.® Blood DNA Maxiprep Kit-tel (VWR International Kft., Debrecen) izolált genomiális DNS-mintát használtunk.

A TSC1 és TSC2 gének valamennyi exonjának amplifikálásához polimeráz-láncreakciót (PCR) végeztünk az általunk tervezett exonspecifikus primerpárok használatával. A PCR-t követően a termékeket bidirekcionális 
Sanger-szekvenálással analizáltuk ABI 3500 Genetic Analyzer szekvenáló (Thermo Fisher Scientific, Waltham, MA, Amerikai Egyesült Államok) segítségével, BigDye terminátorreagens (Thermo Fisher Scientific) felhasználásával. A szülők hordozósági vizsgálatát szintén ezzel a módszerrel, PCR-technikával és Sanger-szekvenálással végeztük.

A nagyobb génátrendeződések vizsgálatát multiplex ligatiofüggő próbaamplifikációs (MLPA-) technikával végeztük, amely exonspecifikus ligálási lépésből, fluoreszcensen jelölt univerzális primerekkel történő PCRamplifikációból és a keletkezett termékek fragmentanalíziséből áll. A módszer egy vagy több exon deletiójának vagy duplikációjának detektása mellett akár a teljes gén kópiaszám-változásának kimutatására alkalmas. Az MLPA-analízis a kereskedelemben kapható kittel történt, a gyártó cég leírása alapján (MRC Holland, Amszterdam, Hollandia).

\section{Eredmények}

Mivel a TSC1 és TSC2 gének Sanger-szekvenálása és MLPA-analízise során eltérés nem volt kimutatható, a beteg DNS-mintáját kollaboráció keretében külföldi genetikai laboratóriumba küldtük teljesexom-szekvenálás (WES) elvégzése céljából. A WES során az SLC12A5génben egy heterozigóta c.1417G>A misszensz eltérést detektáltak, mely egy valin-izoleucin cserét eredményez a fehérje 473-as aminosavpozíciójában (p.Val473Ile). A detektált eltérés a szakirodalomban eddig ismeretlen, különböző perdikciós szoftverekkel vizsgálva eltérő megítélésű, a külföldi kollaborációs laboratórium beszámolójában VUS-ként (variant of uncertain significance) klasszifikált. A fenotípussal összevetve, a szakirodalomban az idiopátiás generalizált epilepszia (IGE) 14-es típusaként ismert epilepsziaszindróma diagnózisát tá- masztja alá. A szülők hordozósági vizsgálata során az édesanya a vizsgált mutációra nézve normál genotípusúnak bizonyult, míg a tünetmentes édesapánál is kimutattuk a gyermeknél észlelt heterozigóta c.1417G >A miszszensz mutációt az SLC12A5-génben.

\section{Megbeszélés}

Az SLC12A5-gén terméke egy, a központi idegrendszerben expresszálódó kálium-klorid-kotranszporter (KCC2) fehérje, a kation-klorid-kotranszporter géncsalád tagja. A KCC2 normál múködése alacsony intracelluláris $\mathrm{Cl}^{-}$-koncentrációt eredményez az érett neuronokban, ami elengedhetetlen a megfelelő szinaptikus gátlás kialakulásához [2]. Régóta feltételezik, hogy az SCL12A5gén defektusa, így a KCC2 fehérje expressziójában és múködésében bekövetkező változások felelősek az amúgy precízen szabályozott, gyors posztszinaptikus GABAerg-gátlás elégtelenségéért és a csökkent hiperpolarizációért, melyet különböző neurológiai és pszichiátriai betegségek (például skizofrénia) kialakulásával hoztak összefüggésbe [3].

A szakirodalomban azonban eddig csak kevés esetben számoltak be az SLC12A5-gén mutációi következtében létrejövő monogénes betegségekről. Az utóbbi években az SLC12A5-génben azonosított variánsokat két igen eltérő fenotípussal járó epilepsziaszindróma kialakulásával hozzák összefüggésbe: mindkét allél mutációja esetén egy súlyos lefolyású korai infantilis epilepsziás encephalopathia, míg az egyik allél mutációja esetén egy jóval enyhébb lefolyású idiopátiás generalizált epilepszia kialakulása várható.

Kable és mtsai idiopátiás generalizált epilepsziás betegeket vizsgálva két különböző heterozigóta, aminosavcserével járó variánst (R952H és R1049) azonosítottak az SLC12A5-génben kanadai francia populációban.

1. táblázat |Az irodalomban eddig közölt SLC12A5-mutációk típusai és a betegek fenotípusa

\begin{tabular}{|c|c|c|c|c|c|}
\hline Gén & Nukleotidszintű eltérés & Proteinszintű eltérés & Öröklődés & Fenotípus & Referencia \\
\hline \multirow[t]{14}{*}{ SLC12A5 } & c. $1417 \mathrm{G}>\mathrm{A}$ & p.V473I & $\mathrm{AD}$ & IGE-14 & A jelen vizsgálat \\
\hline & c. $2855 \mathrm{G}>\mathrm{A}$ & p.R952H & $\mathrm{AD}$ & \multirow{2}{*}{ - IGE-14 } & \multirow{2}{*}{ Kahle, 2014} \\
\hline & c. $3145 \mathrm{C}>\mathrm{T}$ & p.R1049C & $\mathrm{AD}$ & & \\
\hline & c. $1277 \mathrm{~T}>\mathrm{C}$ & p.L426P & AR, compound & \multirow{3}{*}{ EIMFS } & \multirow{3}{*}{ Stödberg, 2015} \\
\hline & c. $1652 \mathrm{G}>\mathrm{A}$ & p.G551D & heterozigóta & & \\
\hline & c. $932 \mathrm{~T}>\mathrm{A}$ & p.L311H & AR, homozigóta & & \\
\hline & c. $279+1 \mathrm{G}>\mathrm{C}$ & p.E50_Q93del & AR, compound & \multirow{6}{*}{ EIMFS } & \multirow{6}{*}{ Saitsu, 2016} \\
\hline & c. $572 \mathrm{C}>\mathrm{T}$ & p.A191V & heterozigóta & & \\
\hline & c. $967 \mathrm{~T}>\mathrm{C}$ & p.S323P & AR, compound & & \\
\hline & c. $1243 \mathrm{~A}>\mathrm{G}$ & p.M415V & heterozigóta & & \\
\hline & c. $953 \mathrm{G}>\mathrm{C}$ & p.W318s & $\mathrm{AR}$, compound & & \\
\hline & c. $2242 \_2244 \mathrm{del}$ & p.S748del & heterozigóta & & \\
\hline & c. $1196 \mathrm{C}>\mathrm{T}$ & p.S399L & $\mathrm{AR}$, compound & \multirow{2}{*}{ EIMFS } & \multirow{2}{*}{ Saito, 2017} \\
\hline & c. $2639 \mathrm{G}>\mathrm{T}$ & p.R880L & heterozigóta & & \\
\hline
\end{tabular}

$\mathrm{AD}$ = autoszomális domináns; $\mathrm{AR}$ = autoszomális recesszív; EIMFS = korai migráló fokális epilepszia; IGE-14 = az idiopátiás generalizált epilepszia 14-es típusa 
In vitro funkcionális vizsgálatokkal kimutatták a kloridkiáramlási kapacitás csökkenését a mutációt hordozó sejteken. A variánsok előfordulását tünetmentes szülőkben az inkomplett penetranciával magyarázták [4].

Stödberg és mtsai WES-vizsgálattal két különböző család négy érintettjében compound heterozigóta, illetve homozigóta mutációt mutattak ki az SLC12A5-génben klinikailag korai migráló fokális epilepsziás betegekben (EIMFS) [5]. A szerzők munkájukban in vitro funkcionális vizsgálatokkal kimutatták, hogy a mutációk csökkentik a gén expresszióját, kórossá válik a poszttranszlációs modifikáció, és a transzportfunkció csökkenése a normális szinaptikus gátlás csökkenéséhez, azaz az idegsejtek fokozott excitabilitásához vezet. Később Saitsu és mtsai négy EIMFS-fenotípusú betegben három különböző, az SLC12A5-gént érintő compound heterozigóta mutációt, majd Saito és mtsai további egy compound heterozigóta mutációt közöltek $[6,7]$. Az irodalomban eddig közölt SLC12A5-gén-mutációkat az 1. táblázat összesíti.

A betegünk tünetmentes édesapjánál is kimutatható mutációt, Kable és mtsai megfigyeléséhez hasonlóan, az inkomplett penetranciával magyarázzuk.

\section{Következtetés}

Esetünk jól példázza azt, hogy a 'genetikai epilepszia' terminológia nem egyenlő az 'öröklődő epilepszia' kifejezéssel. A génmutáció megléte szükséges feltétele a betegség kialakulásának, de a pontos fenotípus, kórlefolyás, prognózis ez alapján nem prediktálható.

Bemutatott esetünkben a bőrtünet és az epilepszia együttes előfordulása a neurocutan szindróma irányába mutatott, a sclerosis tuberosa diagnózisát azonban genetikai vizsgálattal megerósíteni nem tudtuk. A pontos diagnózis felállítása WES-vizsgálat elvégzésével vált lehetővé. Az eddig az irodalomban nem ismert eltérés a fenotípussal összevetve megerósítette a genetikus generalizált epilepszia diagnózisát. Más szerzőkhöz hasonlóan úgy gondoljuk, hogy az új generációs szekvenálási technikáknak, azokon belül is a WES-vizsgálatnak létjogosultsága van az epilepsziás betegek diagnosztikus algoritmusában [8].
Anyagi támogatás: Ez a munka az OTKA K119540, GINOP-2.3.2-15-2016-00039, az EFOP-3.6.3VEKOP-16-2017-00009, valamint az NKFI PD 115677 támogatásával jött létre.

Szerzői munkamegosztás: T. Á. a klinikai részt és a megbeszélést, Sz. R. és B. G. a módszerek és az eredmények részt írta. K. E. végezte a molekuláris genetikai vizsgálatokat és kiértékelte az eredményeket. H. K. és H. M. a beteget vizsgálták. M. B. véleményezte és javította a kéziratot. A cikk végleges változatát valamennyi szerző elolvasta, jóváhagyta.

Érdekeltségek: A szerzőknek nincsenek érdekeltségeik.

\section{Irodalom}

[1] Scheffer IE, Berkovic S, Capovilla G, et al. ILAE classification of the epilepsies: position paper of the ILAE Commission for Classification and Terminology. Epilepsia 2017; 58: 512-521.

[2] Hübner CA, Stein V, Hermans-Borgmeyer I, et al. Disruption of $\mathrm{KCC} 2$ reveals an essential role of $\mathrm{K}-\mathrm{Cl}$ cotransport already in early synaptic inhibition. Neuron 2001; 30: 515-524.

[3] Tao R, Li C, Newburn EN, et al. Transcript-specific associations of SLC12A5 (KCC2) in human prefrontal cortex with development, schizophrenia, and affective disorders. J Neurosci. 2012; 32: 5216-5222.

[4] Kahle KT, Merner ND, Friedel P, et al. Genetically encoded impairment of neuronal KCC2 cotransporter function in human idiopathic generalized epilepsy. EMBO Rep. 2014; 15: 766-774.

[5] Stödberg T, McTague A, Riuz AJ, et al. Mutations in SLC12A5 in epilepsy of infancy with migrating focal seizures. Nat Commun. 2015; 6: 8038

[6] Saitsu H, Watanabe M, Akita T, et al. Impaired neuronal KCC2 function by biallelic SLC12A5 mutations in migrating focal seizures and severe developmental delay. Sci Rep. 2016; 6: 30072.

[7] Saito T, Ishii A, Sugai K, et al. A de novo missense mutation in $S L C 12 A 5$ found in a compound heterozygote patient with epilepsy of infancy with migrating focal seizures. Clin Genet. 2017; 92: 654-658

[8] Dunn P, Albury CL, Maksemous N, et al. Next generation sequencing methods for diagnosis of epilepsy syndromes. Front Genet. 2018; 9: 20. 